This item was submitted to Loughborough's Research Repository by the author.

Items in Figshare are protected by copyright, with all rights reserved, unless otherwise indicated.

\title{
'Physics Envy', cognitive legitimacy or practical relevance: dilemmas in the evolution of management research in the UK
}

PLEASE CITE THE PUBLISHED VERSION

http://dx.doi.org/10.1111/j.1467-8551.2011.00766.x

\section{PUBLISHER}

(C) The Author(s) British Journal of Management ( B British Academy of Management. Published by Blackwell Publishing Ltd.

\section{VERSION}

AM (Accepted Manuscript)

\section{LICENCE}

CC BY-NC-ND 4.0

\section{REPOSITORY RECORD}

Thomas, Howard, and Alexander D. Wilson. 2019. "'physics Envy', Cognitive Legitimacy or Practical Relevance: Dilemmas in the Evolution of Management Research in the UK". figshare. https://hdl.handle.net/2134/14771. 
This item was submitted to Loughborough's Institutional Repository (https://dspace.lboro.ac.uk/) by the author and is made available under the following Creative Commons Licence conditions.

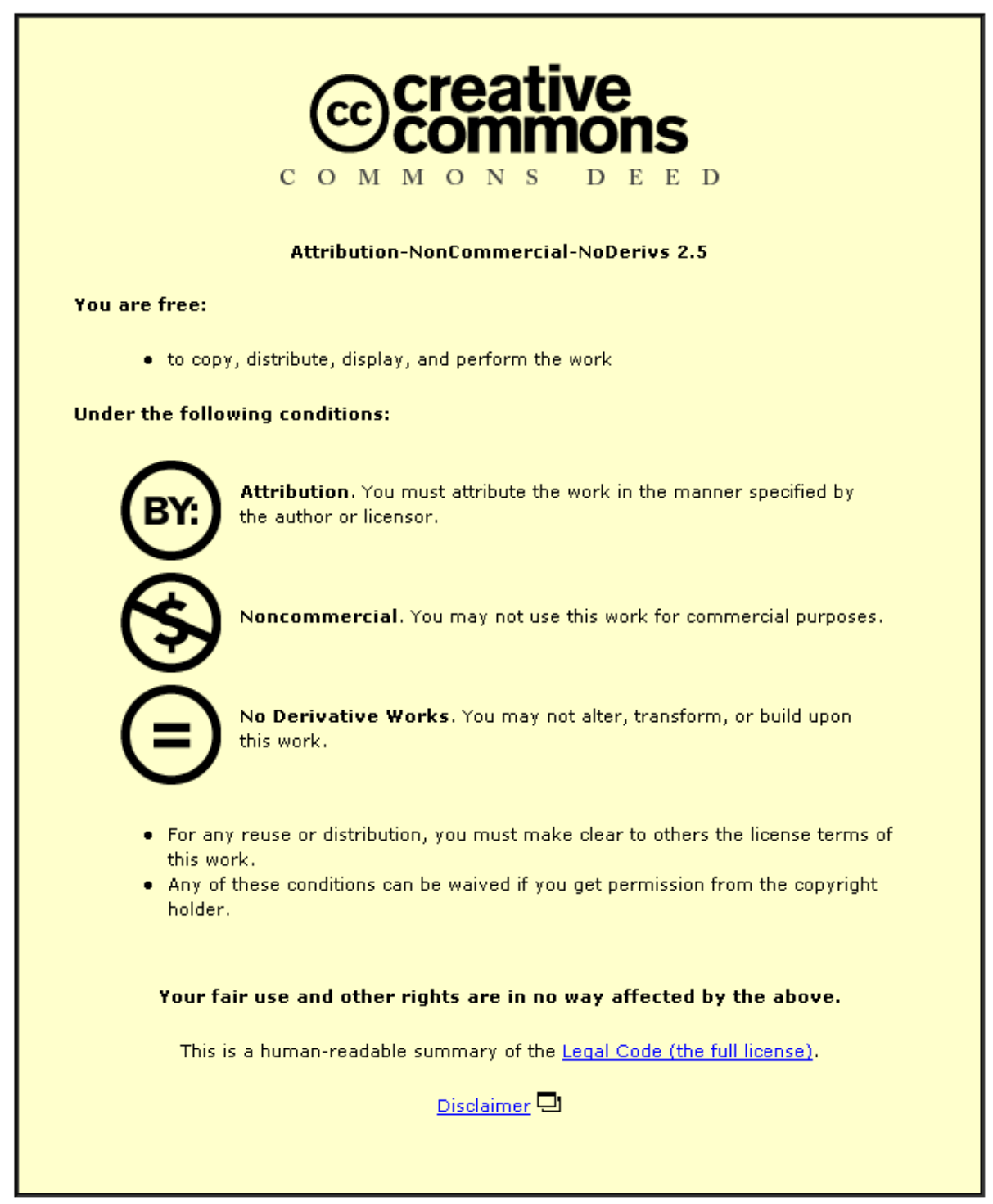

For the full text of this licence, please go to: http://creativecommons.org/licenses/by-nc-nd/2.5/ 


\title{
'Physics Envy', Cognitive Legitimacy or Practical Relevance: Dilemmas in the Evolution of Management Research in the UK.
}

\author{
Howard Thomas
}

Dean, LKCSB Chair in Strategic Management, Lee Kong Chian School of Business, Singapore

HOWARD THOMAS, B.Sc., M.Sc. London, M.B.A. Chicago, Ph.D., D.Sc. Edinburgh, Fellow of the British Academy of Management, American Academy of Management, Academy of Social Sciences, Institute of Directors and the Strategic Management Society. He is LKCSB Chair in Strategic Management and Dean of Lee Kong Chian School of Business at Singapore Management University. He came to Singapore from Warwick Business School, where he was Dean for 10 years. Prior to that appointment, he was Dean of the College of Commerce and Business Administration and was James F. Towey Professor of Strategic Management at the University of Illinois at Urbana Champaign (U.I.U.C.).

He is the past Chair of AACSB International, the Association of Business Schools (A.B.S) in the UK and the Global Foundation for Management Education (GFME). He was Vice President for Business Schools for EFMD for 2000-07.

howardthomas@smu.edu.sg

\section{Alexander D. Wilson*}

Warwick Business School, University of Warwick, United Kingdom

ALEX WILSON, B.A. Leeds, M.A., Ph.D. Warwick, is research fellow at Warwick Business School. Research interests include the relationship between organisations and novel technology, the social construction of technology, organisational resilience, the evolution and development of management research and the role of business schools.

+44 (0)24 76573115

alexander.wilson@wbs.ac.uk

${ }^{*}$ corresponding author

Word Count: 5,700 (excluding bibliography and tables)

Keywords: Legitimacy, conflict, discipline-based research, management research, continuity, change. 


\title{
'Physics Envy', Cognitive Legitimacy or Practical Relevance: Dilemmas in the Evolution of Management Research in the UK.
}

\author{
Abstract: \\ We reflect on the key debates and controversies that face business schools and \\ management research. This paper frames the core debates in terms of \\ organisational legitimacy as a lens through which to analyse the rapid rise and \\ development of business schools in the UK. The production of management \\ knowledge straddles the precarious divide between academic rigour and practical \\ relevance. We argue that the conflicting sources of legitimacy could be undermining \\ the international research competitiveness of UK schools and that a far-reaching \\ review of management education and research is necessary.
}

\section{Introduction:}

A quarter of a century is a landmark occasion and certainly one for celebration. As part of this special issue to celebrate twenty five years of the British Journal of Management we take the opportunity to reflect on the evolution, quality and reputation and research performance of business schools in the UK. We explore this through the lens of legitimacy, arguing that business schools face increasing ambiguity and conflict concerning their legitimate form and function. Specifically, this paper addresses management research and interrogates to what extent the current discipline-based research model is both suitable and sustainable for UK business schools. 
There is no shortage of debate and controversy surrounding business schools. Specifically, there is a growing body of literature and commentary that addresses allegations of failure (Bennis and O'Toole, 2005;Bones, 2009), knowledge creation (Chia and Holt, 2008; Tranfield and Starkey, 1998), issues of pedagogy

(Antonacopoulou, 2010;Grey, 2004; Jarzabkowski and Whittington, 2008), the history and origins of management education (Grey, 2010;Antunes and Thomas, 2007) as well as ideology, purpose and leadership (Davies and Thomas, 2009; Fragueiro and Thomas, 2011). The waves of financial crises, scandals and controversy have sharpened the focus on business schools and their relationship with management in general. And within universities business schools are valued more for their financial strength than their intellectual scholarship (Bok, 2003), in strategic terms, 'cash cows' for universities (Starkey and Tiratsoo, 2007). Business schools also have Field Code Changed Field Code Changed been much maligned in the press which implicates management education as a contributory agent in the recent financial crisis. Equally, the financial crisis has intensified debate among scholars about the role and purpose of business schools (see: Currie, Knights and Starkey, 2010). For other authors too, the financial crisis signalled a need to reappraise the role of business schools and the kinds of mangers and management practice they are producing (Podolny, 2009;Starkey and Tempest, 2009). These issues all stand out as core debates connected with the role of business schools. We do not provide coverage of all of these, often highly nuanced, debates here. Instead, and taking stock of these emerging debates, we review the role and purpose of business schools with regard to management research and management education. We employ the term 'physics-envy' coined by Barwise (The Field Code Changed Economist, 2007) to describe the dominant theory driven, discipline-based research 
mode found in management research and its currency in establishing management as a legitimate academic discipline.

\section{Emergence and growth of UK business schools}

The business school, as a constituent of the university system, is a relatively recent phenomenon and while we often think of business schools as a broadly American innovation, the inclusion of business and management knowledge as part of higher education began in Europe with various models of trade or vocational commercial schools. However, the initial phases that saw business schools emerge as significant constituents within universities began in the late 1950s and early 1960 s. The Ford and Carnegie reports in the US (see: Bennis and O'Toole, 2005) set in place a model for management research and education founded upon rigorous, discipline-led scholarship with a strong focus on analytic models and reductionism. In the UK, a similar landmark event was the publication of Lord Franks' report (1964) which stressed the national importance of improving the quality of management education (Williams, 2010). It was this report that led to the establishment of two university-based business schools in London and Manchester in 1965. Created as semi-autonomous university departments, the two schools were designed with curricula modelled on the provision of US-style MBA programs offered by American elite schools (e.g. Harvard, Chicago, and Massachusetts Institute of Technology), the net effect being: “...the development of business schools towards a research and discipline-led focus with an emphasis on scientific method, research and knowledge creation and a strong focus on graduate education in business" (Antunes and Field Code Changed Thomas, 2007, p.384). Engwall and Danell (this issue) chart the development of UK business schools in far greater detail than is possible here (see also: Fragueiro and Thomas, 2011; Williams, 2010). 
A pronounced characteristic of the evolution of management education is its phenomenal expansion, a feature which has made business schools a business in their own right (Starkey and Tiratsoo, 2007). The sheer scale of management education in the UK pays testament to the growth management education has experienced over a relatively short period: For example, for the academic year 19978 there were 222,840 students (full-time, part-time and across all degree levels) studying business and management in UK higher education institutions (Higher Education Statistics Agency, 1999), by 2008-9 the sector catered for 330,255 business and management students (Higher Education Statistics Agency, 2010). Furthermore, the latter figure represents nearly $14 \%$ of the entire student body for the same period meaning that management and business subjects hold the greatest proportion of students for any higher education subject area [note: the recent publication by the Association of Business Schools on the role of business schools provides in-depth commentary of the growth of the field (see: Cooke and Galt, 2010)]. The scale and continued growth of management education is remarkable and something that has not been paralleled across other academic disciplines.

In the period since the Franks report, UK business schools have faced major challenges from both their rapid growth and being accepted as a legitimate interface between management theory and practice. First, there was the challenge of building a business school faculty of those who would teach and research the multifaceted area of management without an adequate supply of business and management academics. Initially departments were led by academics trained in single discipline UK schools (for example, economists) or from US doctoral programmes in business; it would take years before business school faculty began to emerge from UK doctoral programmes. Leading up to the inception of BAM it was recognised that research 
capacity was limited and management research lacked any overarching coordination to firmly establish management as a discipline. A feature that compounded this problem and stifled the development of the discipline was the lack of research funding. Despite the extraordinary growth of business schools, management academics represented $30-40 \%$ of social sciences faculties, yet attracted only $10 \%$ of Economic and Social Research Council (ESRC) funding. As McKiernan and Masrani reflect in their history of BAM $(2007$, p. 2), the discipline of management faced issues of "...Labour supply, funding restrictions and flows, research prominence and exposure, and limited journal outlets created sufficient pressure in the UK system for the formation of a separate national academy of management." The need to establish a national academy (BAM) in 1986 paralleling the US Academy of Management and latterly the Advanced Institute of Management (AIM) as an umbrella research organisation for management funded by the ESRC in 2002 can be seen in the context of a crisis of legitimacy for business schools. This signalled the problem of addressing appropriate unified representation of the field at the national level (McKiernan and Masrani, 2007). The following sections address the concept of legitimacy and the research challenges it poses for business schools.

\section{Business schools and the need for legitimacy}

Business schools are fairly recent incumbents in the sphere of academe and have grown at an extremely rapid rate, some examples holding as many staff as an entire university faculty. Despite this impressive level of growth, business schools have attracted wide criticism with critics located within business schools and the broad academic community, management practitioners, the press and media. For each of these stakeholders, business schools are not regarded as fully legitimate organisations. This is problematic given that "Legitimacy is a generalized perception 
or assumption that the actions of an entity are desirable, proper, or appropriate within some socially constructed system of norms, values, beliefs, and definitions" (Suchman, 1995, p. 574). Legitimacy enables organisations to appear appropriate and desirable, and consequently increase the likelihood of securing resources (Parsons, 1960). It also conveys a platform for how organisations are understood, meaning they are not only worthy in the Parsonian sense, but are trustworthy on the basis that there is a rationale explaining what the organisation is doing and why (Jepperson, 1991). Consequently, any gap in the social construction of organisational legitimacy could have negative effects: "A legitimacy deficit may mean that an organisation is susceptible to claims that it is negligent, irrational or (at least in its current form) unnecessary." (Sillince and Brown, 2009, p. 1830). Rather than an all-out legitimacy deficit, the criticisms of business schools signal more that there are areas of ambiguity, conflict and uncertainty around their legitimate form. Where there are conflicting sources of legitimacy, there is amplified scope for innovative responses where organisations and individuals shape their institutional environment (Zucker, 1987, p. 451): “...organisations may seek legitimation of their activities Field Code Changed through active control or shaping of the institutional environment (Pfeffer and Salancik, 1978, chpt. 8;Dowling and Pfeffer, 1976) in order to gain access to societal Field Code Changed Field Code Changed resources, thus ensuring their long-term survival (Scott and Meyer 1983)." These institutional entrepreneurs engage in actively shaping 'the rules of the game' to change the institutional order: For example, Czarniawska (2009) has argued that the role of institutional entrepreneurs was essential in the development of the London School of Economics who safeguarded and maintained capital and social resources to ensure its survival. 
Among business schools we argue that there are key sources of legitimacy which act as reference points to structure themselves and their relationships within the organisational field (Fiegenbaum and Thomas, 1995;Porac, Thomas and BadenFuller, 2011). The interface between the organisational field and the global population of business schools provides material and cognitive cues for legitimate action. However, as our introductory paragraphs explained, there is tension about the legitimate role and purpose of business schools.

To help identifiy sources of legitimacy for business schools we examine their history and development alongside key reference points and relationships within their field. We extend Antunes and Thomas' (2007) social constructivist perspective on the evolution of business schools to include sources of legitimacy in each phase of development:

Table 1 here

The multiple sources of legitimacy begin to explain contrasting organisational responses by business schools to their institutional setting. For example, national differences between business schools, the emergence of strategic groups among both business schools (Thomas and Li, 2009) and MBA programmes (Segev, Raveh and Farjoun, 1999) indicate some of the organisational efforts to gain legitimacy in order to secure resources and their long term survival. The capability of business schools to shape what is, and processes of being, legitimate are deeply entrenched in their history and evolution as part of the university system. A legacy of the ' 3 ' generation' (as characterised in Table 1) is the core activity of research production and the legitimating performance measures that stem from this including citation 
measures, international ranking, national audits and accreditation standards. This is in stark contrast to the $1^{\text {st }}$ generation schools seen in the first row of table 1 , where business schools provided administrative and commercial training for the thenemerging occupational class of managers.

Why is legitimacy important to business schools? First, an organisation must have (or appear to have) legitimacy for its long-term survival. The evolution of the business school illustrates how, in order to integrate and survive as part of the university system, an intense and rigorous approach to management education was adopted. But, as Schoemaker (2008) stresses, the paradigm 'with its strong focus on analytic models and reductionism is not well suited to handle the ambiguity and high rate of change facing many industries today'. Secondly, there are ramifications for performance. There is growing evidence that university research serves increasingly as a commodity product, which is disjointed from the liberal pursuit of knowledge, a principle on which universities were founded (Willmott, 1995), and from the needs of managers to solve management problems. Indeed, the extent to which business schools compete for the highest rankings, the best cadre of students and faculty, the greatest number of citations in the highest impact journals and secure the largest possible slice of research funding suggests that schools exist in an era of 'hyper-competition' (Starkey and Tiratsoo, 2007). This presents a serious problem of Field Code Changed maintaining organisational legitimacy. On the one hand business schools are to provide rigorous and scientific understanding of management to satisfy the needs of academe, while on the other to provide relevant findings from research and improve management skills through teaching. It is this juxtaposition that is central to our questioning whether the 'physics envy' approach to management research is desirable and sustainable for UK business schools. In the following sections we 
comment on the UK landscape of management research and emphasise the competing sources of legitimacy from practical relevance and academic rigour. Finally, we examine the implications for UK business schools of systematic accreditation and rankings. We suggest that national systems of ranking and performance assessment may impede - rather than enhance - the performance of UK schools as internationally competitive business schools.

\section{The UK Landscape of Management Research:}

In the spirit of Lord Franks report (and the Carnegie and Ford reports in the US), the development of a scientific, rigorous mode of enquiry and academic peer-review would raise the bar for standards in management research. At the same time, this would position business schools as the primary location for management knowledge production and would bolster their legitimacy as constituents in universities and providers of management education. The shift that saw business schools emerge within the university system in combination with a growing demand for business courses poses fundamental questions about the processes of knowledge production across the management discipline. In Tranfield and Starkey's (1998: 343) terms, much of this debate revolves around two issues, its fragmentation and its applied nature. The issue of fragmentation suggests that while management education is ' $a$ broad church', there are underlying fissures between constituents. Management research includes an array of ideologies and values which incorporates "a wide range of ontological and epistemological views, leading to vigorous and ongoing debate within the research community" (Tranfield and Starkey, 1998, p. 347). the interface between academe and management practice where, arguably, the 
needs of neither are met! Crainer and Dearlove (1998, p. 48) caricature this predicament with business schools portrayed as schizophrenic organisations that must demonstrate their capacity as bona fide academic institutions, improve knowledge to provide solutions to management problems and at the same time perform as businesses. To finesse their point, there are two sources of legitimacy with which business schools must interface: First, there is an academic component where, first and foremost, business schools must demonstrate that they have a place in academe. Historically, for business schools, this has followed a 'scientific' model, orientated towards the intensification of knowledge about and theories of management to secure a legitimate position within the university system. This has entailed the activities of scholarly publication and also developing intellectual capacity through doctoral programmes (McKiernan and Masrani, 2007) - hence the Field Code Changed term 'physics envy' is particularly salient to describe the emulation of knowledge production by scientific disciplines. Secondly, there is a fundamental question about the purpose of management research; is management research for or about managers? The tensions between theoretical rigour and practical relevance in management research marks a potential conflict between legitimacy providers for business schools. Indeed, Bennis and O'Toole (2005) ask why 'business schools have embraced the scientific model of physicists and economists rather than the professional model of doctors and lawyers.' These positions have clear implications for what constitutes legitimate activities of a business school and, as Ivory et al. (2006) have argued, create conflicting themes in the debate about business schools. It should be acknowledged that the management education model outlined by Lord Franks was intended to provide national business leaders who would become future captains of industry while at the same time attempting to reconcile the tensions 
between the needs of industry and the interests of the academic community. Even at the outset of integration with the university system there were concerns that the original model had been 'hijacked' by academics (Whitley, Thomas and Marceau, 1981). The tensions between practical relevance and academic rigour go to the heart of the role and purpose of business schools. As Schoemaker notes (2008, p. 119) business educators have always been prised on the horns of a dilemma pitting academic rigour against practical relevance, notwithstanding Kurt Lewin's astute observation that 'nothing is as practical as a good theory'. Table 2 emphasises the conflict between the broad range of legitimacy providers for business schools.

\section{Table 2 here}

That is, organisational behaviours corresponding to academic and practical concerns. We use the archetypal criticisms of business schools identified in Ivory et al. (2006) to illustrate the conflicting sources of legitimacy which are framed here as corresponding to a perceived lack of either practical relevance or academic rigour. Table 2 presents some of the point and counter-point positions that have emerged in debates around the role and purpose of business schools. Across the five areas of research, teaching, MBAs, impact for practice and output, it is clear that business schools face some fundamental tensions in their core activities. Although these five areas are very much interlinked components of business schools, our exposition and argument around the dilemmas facing management research in the UK focuses on research and impact for practice. In defence of business schools and stepping back from this caricatured divide, there is evidence to suggest that management research has produced some highly relevant and extensively used theories (cf. Table 5, 
AACSB, 2007). We must, however, be careful not to assume that these started life as practicable, as opposed to theoretical, contributions to management in the first place. The fact that some management theories have been adopted in practice does not imply that they were developed to a particular recipe with immediate practical relevance. Indeed, the study by Baldridge, Floyd and Markóczy (2004) argues that academic quality and practical relevance are weakly correlated. Potentially, this suggests there may be greater currency in discussing patterns of knowledge consumption (Gabriel, 2002) as opposed to, for example, discrete measures of practical relevance. Thinking about management knowledge in terms of patterns of consumption helps override the artificial dichotomy of theory versus practice and provides a more organic conceptualisation of the interface between managers and business schools' research outputs. Two possible strategies to help manage the conflicting sources of legitimacy can potentially be found in the consumption and performance measures of management research: First, there is much work to be done to improve the context of research, the engagement with managers and uptake of research through translating findings adequately. Second, the performance measures and mechanisms of business school research need to be critically appraised with regard to whether they demonstrably enhance the state of the management discipline or management practice.

\section{Business schools and management research}

The perceived imbalance between theory and practice, or rigour and relevance, in management research remains a persistent challenge to the legitimacy of business schools. However, there are particular themes and strands not often given prominence within current debates and we propose there are areas where inroads can be made into bridging the double hurdles of rigour and relevance. A theme that 
consistently surfaces is the need for practice engagement by management research as a means to span the perceived divide. However, in formulating strategies to address this problem, it is useful to know the scale of the theory-practice divide. Evidence from McGrath (2007, p. 1372) suggests there is a considerable gap between key issues on managers' minds (which she derived from the most frequently asked questions at the 2007 conference "The CEO Agenda" with delegates from more than 100 CEOs of the world's largest firms) and the topics of papers published throughout the 2006 volume of the Academy of Management Journal. As a crude measure, this signals a distant relationship between theory and practice.

Potential solutions to this problem come from practice engaged research and broad reform of the role and purpose of business schools. Examples of some of the approaches to practice engaged research are shown in table 3.

\section{Table 3 here}

The strategies for practice engagement in table 3 indicate the extent of debate that surrounds the practical, as opposed to academic, value of management research. What broadly unites these strategies is what McGrath describes as a shift to building a scholarly understanding of phenomena ahead of building and testing theory. Broad reform of management research is one approach to improving practice engagement. Other commentators suggest that business schools are in need of radical reform to not only address the problem of practice engagement, but to redefine their purpose. Alternative models have been suggested for redefining and strengthening the perceived legitimacy of business schools in the eyes of management practitioners and other stakeholders. For example, 'Agora' - an open 
platform for discussion and development (Starkey and Tiratsoo, 2007), schools in the professional model (Bennis and O'Toole, 2005;Khurana, 2007; Khurana and Nohria, 2008;Mintzberg, 2004), or business schools in a societally integrated, public interest model (Ferlie, McGivern and De Moraes, 2010) have been proposed as alternatives to the incumbent scientific-academic model.

Clearly, developing practice engagement is an important remedial step whether it is through how we conduct management research or redefining the role of business schools. However, a crucial sticking point is in the paucity of our synthesis of the voice of practice. The voice of practice is predominately an internally driven monologue within the academic community. The voice of practice is, in essence, lost. Often, benchmarks and metrics for engagement with practice are internally derived and we also rely on proxy measures such as media coverage to signal successful engagement with practitioners. In this scenario, management theory exists inside of business schools and management practice occurs out there in the world of business - two distinctly separate arenas. As the authors have previously argued: "Taken to its logical conclusion, what practice is and where practice happens is often at the disposal of the researcher" (Thomas and Wilson, 2009, p. 678). Without finding the voice of practice, the activity of practice engagement is reduced to a bounded process by researchers of devising and solving managerial problems, from which the voice of practice is absent. If we consider this against the sources of organisational legitimacy for business schools there are barriers to moving towards practice engaged modes of management research.

Of course, business schools like any other institutionalised organisational form are subject to institutionally mediated, and expected legitimate behaviours, which are powerful pressures for continuity rather than change. (See Wilson and McKiernan
Field Code Changed

Field Code Changed

Field Code Changed

Field Code Changed

Field Code Changed

Field Code Changed 
(this issue). Incentives to locate the voice of practice are overpowered by the rewards to both faculty and school from publication in A-list, theoretically rigorous journals. In consequence, business schools do not have the facility to switch freely, for example, to a 'professional' model of management education because the associated changes would compromise the legitimacy of the school. This does not detract from the utility these debates bring to the business school debate and helping to improve management education, rather it underlines the strategic importance of engaging in legitimate behaviour. These expected, legitimate behaviours are significant barriers to change found in the systems of homogeneity, standardization and reward that persist in the architecture of accreditation, citation counts and school rankings. Legitimacy is conferred because of their ability to infer a level of scholarly performance against which to measure performance and to compare against other schools. What are the key metrics and measures of performance for business schools and how, if at all, do they confer legitimacy (Barreto and Baden-Fuller, 2006)? Thomas (2007) suggests from a managerial perspective that there should be financial, operational and organisational effectiveness measures of performance. Given financial stability, he argues that the scholarly dimension should include internal measures of faculty, student and teaching quality and external measures of positioning such as reputational rankings (league tables), research rankings and accreditation.

\section{Quality control? Rankings, accreditation and business schools.}

An enduring legacy of the Franks report in the UK (and the Carnegie/Ford reports in the US) is the ongoing issue of cognitive legitimacy for management educators. In the process of establishing themselves as constituents of the university system, business schools had to meet the challenge of gaining cognitive legitimacy through 
claims of scientific rigour and objectivity (Khurana, 2007, p. 68) and to some extent this challenge is deeply embedded in systems of ranking and accreditation (Wedlin, 2011). Our intention here is to examine the consequences of various systems of ranking and accreditation for the organisational legitimacy of business schools; there is not the scope to have elicited the politics or procedure of the various rankings.

Research output is a dominant performance metric for business schools. This is the case whether ranking occurs as part of comparisons in the media or national audits of university performance such as the research assessment exercises in the UK. High-profile media rankings in the UK include, for example, the Financial Times and the Times Good University Guide, which incorporates research output along with other measures as a component of their ranking. Other ranking factors used particularly in media rankings such as the FT (Financial Times) Global MBA rankings, include the average increase in salary of alumni, career progress, alumni recommendations, teaching quality and the international mix of staff and students. Research ranking is also conducted at a national level. In the UK the Research Excellence Framework (REF) succeeds the former national Research Assessment Exercise (RAE) as a means of benchmarking the performance of universities and for the future allocation of funding. Wilson and McKiernan (this issue) are able to dissect more comprehensively the problematic nature of national research rankings.

The culture of measurement and benchmarking business school research output leads to a mechanism for allocating resources, both economic and social capital. The 'commodification' of research (and academic work) introduces quasi-market conditions creating intense pressure to produce the highest quality research (Willmott, 1995). Correspondingly, there is considerable debate about what citation counts actually tell us. Mangematin and Baden-Fuller (2008, p. 120) argue that 
research impact should be measured in terms of citations "which is the 'democratic' vote of the scientific community[...] Our approach is common with widely accepted practices in other fields". However, Wensley (2009) argues that citation measures indicate a cloistered 'academic relevance' to our own discipline rather than academic rigour due to the limited subset of journals that are counted typically so called A-list top rated publication outlets. Further, journals are in turn a subset of management knowledge generated by business schools - it has been argued that much of the seminal work and high impact in management comes from non A-list journal publications (Rynes, 2006;Pfeffer, 2007) and books/monographs. For example, it was through books that Penrose's resource-based view and Porter's competitive strategy models emerged in the field of strategic management. This 'tyranny of the rankings' (Khurana, 2007) poses difficult questions about the purpose of business schools and the effect on management research. That is, there is the potential dilemma between what is expected from management research and what yields economic and social reward for business schools. The danger lies where impact and citation scores become the central criterion for assessment of quality and reward in business schools. Put another way, "[r]ather than genuinely fostering relevant knowledge, the emphasis on ranking seems to be driven by a desire to identify winners and losers in a game of academic prestige" (Adler and Harzing, 2009, p. 74).

There is also a question of conflict or congruence between national and international rankings. For example, does elite status in national ranking performance translate into improved international standing? The University of Texas at Dallas world research ranking includes only one UK business school, London Business School, in the top 100 business schools based on research contribution. (see Table 4)

Field Code Changed

Field Code Changed

Field Code Changed 
Table 4 here

Further evidence on this point is provided in the Table 5 below which is derived and adapted from an extensive global survey of the research rankings of business schools based on research publications and citation measures for the period $1992-$ 2005 (Mangematin and Baden-Fuller, 2008).

Field Code Changed

Table 5 provides a listing of some of the top 120 schools in their survey (US schools are omitted since around $70 \%$ of the top 120 are US based and therefore dominate the rankings) based upon four regions, namely the UK, Canada, Europe and Asia/Australia. Three rankings are given, namely, first, the Mangematin and BadenFuller (2008) global rankings; the Research Rankings derived from the Financial Times Global Surveys and, third, the research rankings derived from the University of Texas at Dallas world research rankings survey.

Broadly, the results in Table 5 demonstrate clearly that the globalisation and growth of management education has led to the evolution of high-quality, research oriented schools in Europe, Asia/Australia as well as the US, UK and Canada. More specifically, while research by the leading elite US schools still dominates (but with a slightly declining market share), both European and Asian schools have 'raised their game' relative to UK schools (see Saunders, Wong and Saunders, this issue). And at least three Canadian schools, Toronto, UWO and UBC, are now on a par with the best US state schools. If this evidence reflects the current situation, only a very small number of UK schools (LBS certainly plus a select few) are producing world-class research. More worrying, although the data are not presented here, only about 15 UK schools have any article counts in the UT Dallas survey (and sometimes they 
result from the work of one UK renowned scholar such as Buckley, Child or Pettigrew). Therefore, there appears to be little or no correlation between the world class research based on the UT Dallas A-journal rankings and the rankings produced by the RAE 2008 research assessment exercise in the UK.

What does this say about the quality of UK management research? Wensley (2009) suggests that there is continued debate about and questioning of management research in the UK relative to other social science disciplines along the following dimensions:

- the questioning of management as a legitimate, academic discipline compared to, for example, economics.

- the perception of capacity shortages of high quality scholars in many business schools.

- the perception of the lower quality of management research, perhaps because of its multi-disciplinary nature, relative to other social science disciplines.

This continuing debate has clearly influenced the difficult relationship between the ESRC and the management education community (Caswill and Wensley, 2007; Wensley, 2009). As noted earlier, individual business schools, the ABS (Association of Business Schools), BAM and others have continually stressed the disparity between research funding for business schools from government sources and the clear student enrolment strength of business schools. Indeed, Caswill and Wensley (2007) catalogue the problematic history between ESRC and UK Field Code Changed management researchers including the BAM inspired Bain Commission on Management Research in the 1990's, the subsequent lobbying, and hope, for the 
establishment of a separate Management Research Council to the founding of the much more impact focussed AIM in 2002 (www.aimresearch.org).

Yet the continued and energising influence of AIM on Management Research in UK should be emphasised strongly. The problem with tables such as the UT Dallas and Mangematin/Baden-Fuller rankings is that they are anchored firmly in the A-journal, discipline based analytic model of business school research developed by the US schools following the Ford/Carnegie reports and, therefore, not surprisingly those schools dominate such ranking. Indeed, as Pfeffer and Fong (2002) point out, too often management research in business schools broadly reflects the disciplinary divisions embedded in the structure of our own organisations which, in turn reinforce the incentive structures - 'publish or perish' - for academics and their career.

However, management is a multi-disciplinary activity. Many of the most important management problems such as sustainability, CSR and risk management have a 'cross-cutting' multi-disciplinary nature. Therefore, for research to have an impact on business it should often be carried out in multi-disciplinary teams with large-scale longitudinal research designs of the type promoted by UK researchers such as the UK Aston studies and the Warwick processual studies anchored by Andrew Pettigrew. In short, we should get rid of the 'physics-based envy' of the disciplinebased research model and emphasise the distinctive, and often inductive, nature of UK management research.

In this respect AIM has been significant in generating high quality applied research sometimes multidisciplinary - and in alleviating the shortage of excellent, skilled researchers in the management field. The challenge for management research is to 
engage and translate management research in both the practice and academic domains to achieve legitimacy.

Accompanying business school rankings, accreditation by internationally recognised bodies (AACSB and EQUIS for business schools and AMBA for MBA programmes) also confers a level of quality for each institution (Zammuto, 2008, p. 260): "Business school accreditation is a quality assurance scheme that certifies that accredited schools have the structures and processes in place necessary to meet their stated objectives and continually improve performance. Such quality standards can be used by organisations to differentiate themselves from competitors." This depicts the role of accreditation bodies as legitimacy providers through their capacity to denote appropriate structures and processes and also that accreditation is a source of competitive advantage to schools through differentiation from competing schools. At the current date around 20 UK schools are accredited, and legitimated, by AACSB and EQUIS - the two most well—known accreditation agencies. AACSB has around 620 ( $70 \%$ US based) and EQUIS 130 accredited schools globally.

\section{Conclusion}

One of the key questions about management research is whether the disciplinebased research model is any longer sustainable or 'fit for purpose'. Rankings are here to stay - whether media or academic driven - and in a hyper-competitive business school world Deans care about their rankings. Given the desire to achieve legitimacy as an academic and management profession there needs to be momentum in balancing the 'purity' of academic research with the practical needs and problems of our management profession. We suggest that there is an urgent need for the twenty-first century equivalent of the 1950's Ford/Carnegie reports and 
this should examine business schools, management education and research, and the future. This inevitably will require changes to the arrangement of legitimacy providers (table 1, column 4) to modify and advance the behaviours of business schools. An issue with which BAM and other influential bodies will have to engage is whether this should entail new and additional stakeholders as legitimacy providers or some impetus for change amongst current constituents. Imperatives include, for example, the need to develop research independently and openly with a critical perspective and to bridge the public/private and corporate/not for profit divides in management practice. 


\section{Bibliography:}

AACSB (2007). 'Final Report of the AACSB International: Impact of Research'. p. 51. Adler, N. J. and A.-W. Harzing (2009). 'When Knowledge Wins: Transcending the Sense and Nonsense of Academic Rankings'. Academy of Management Learning \& Education. pp. 72-95. Academy of Management.

Antonacopoulou, E. P. (2010). 'Making the Business School More 'Critical': Reflexive Critique Based on Phronesis as a Foundation for Impact', British Journal of Management, 21, pp. s6-s25.

Antunes, D. and H. Thomas (2007). 'The Competitive (Dis)Advantages of European Business Schools', Long Range Planning, 40, pp. 382-404.

Baldridge, D. C., S. W. Floyd and L. Markóczy (2004). 'Are managers from Mars and academicians from venus? Toward an understanding of the relationship between academic quality and practical relevance', Strategic Management Journal, 25, pp. 1063-74.

Barreto, I. and C. Baden-Fuller (2006). 'To Conform or To Perform? Mimetic Behaviour, Legitimacy-Based Groups and Performance Consequences*', Journal Of Management Studies, 43, pp. 1559-81.

Bennis, W. G. and J. O'Toole (2005). 'How Business Schools Lost Their Way', Harvard Business Review, 83, pp. 96-104.

Bok, D. C. (2003). Universities in the marketplace : the commercialization of higher education, Princeton University Press, Princeton, N.J. ; Oxford.

Bones, C. (2009). 'A Crisis of Confidence?'. The Economist. London.

Caswill, C. and R. Wensley (2007). 'Doors and Boundaries: A Recent History of the Relationship between Research and Practice in UK Organizational and Management Research', Business History, 49, pp. 293-320.

Chia, R. and R. Holt (2008). 'The Nature of Knowledge in Business Schools', Academy of Management Learning \& Education, 7, pp. 471-86.

Cooke, A. and V. Galt (2010). 'The Impact of Business Schools in the UK'. The Association of Business Schools.

Crainer, S. and D. Dearlove (1998). Gravy training : inside the world's top business schools, Capstone, Oxford.

Currie, G., D. Knights and K. Starkey (2010). 'Introduction: A Post-crisis Critical Reflection on Business Schools', British Journal of Management, 21, pp. s1s5.

Czarniawska, B. (2009). 'Emerging Institutions: Pyramids or Anthills?', Organization Studies, 30, pp. 423-41.

Davies, J. and H. Thomas (2009). 'What do Business School Deans Do? Insights from a UK Study', Management Decision, 47, pp. 1396 - 419.

Dowling, J. and J. Pfeffer (1976). 'Organizational Legitimacy', Pacific Soliological Review, 18, pp. 122-36.

Ferlie, E., G. McGivern and A. De Moraes (2010). 'Developing a Public Interest School of Management', British Journal of Management, 21, pp. s60-s70.

Fiegenbaum, A. and H. Thomas (1995). 'Strategic groups as reference groups: Theory, modeling and empirical examination of industry and competitive strategy', Strategic Management Journal, 16, pp. 461-76.

Fragueiro, F. and H. Thomas (2011). Strategic Leadership in the Business School: Keeping One Step Ahead Cambridge University Press.

Franks Report (1964). 'British Business Schools'. London: The Institute of Management. 
Gabriel, Y. (2002). 'Essai: On Paragrammatic Uses of Organizational Theory A Provocation', Organization Studies, 23, pp. 133-51.

Grey, C. (2004). 'Reinventing Business Schools: The Contribution of Critical Management Education', Academy of Management Learning \& Education, 3, pp. 178-86.

Grey, C. (2010). 'Organizing Studies: Publications, Politics and Polemic', Organization Studies, 31, pp. 677-94.

Higher Education Statistics Agency (1999). 'Table 2e - All HE Students by Subject of Study, Domicile and Gender 1997/98'. In: HESA (ed.).

Higher Education Statistics Agency (2010). 'Table 2e - All HE students by level of study, mode of study, subject of study(\#1), domicile and gender 2008/09'.

Ivory, C., P. Miskell, H. Shipton, A. White, K. Moeslein and A. Neely (2006). UK business schools : historical contexts and future scenarios : summary report from an EBK/AIM Management Research Forum, AIM Research, London.

Jarzabkowski, P. and R. Whittington (2008). 'Directions for a Troubled Discipline: Strategy Research, Teaching, and Practice--Introduction to the Dialog', Journal of Management Inquiry, 17, pp. 266-68.

Jepperson, R. L. (1991). 'Institutions, institutional effects, and institutionalism.'. In: W. W. Powell and P. J. DiMaggio (eds.), The New institutionalism in organizational analysis. pp. 143-63. Chicago; London: University of Chicago Press.

Khurana, R. (2007). From higher aims to hired hands: the social transformation of American business schools and the unfulfilled promise of management as a profession, Princeton University Press, Princeton.

Khurana, R. and N. Nohria (2008). 'It's Time to Make Management a True PROFESSION'. Harvard Business Review.October pp. 70-77. Harvard Business School Publication Corp.

Mangematin, V. and C. Baden-Fuller (2008). 'Global Contests in the Production of Business Knowledge: Regional Centres and Individual Business Schools', Long Range Planning, 41, pp. 117-39.

McGrath, R. G. (2007). 'No longer a stepchild: How the management field can come into its own', Academy of Management Journal, 50, pp. 1365-78.

McKiernan, P. and S. Masrani (2007). 'The History of the British Academy of Management'. British Academy of Management, http://www.bam.ac.uk/uploadedfiles/pdf/bam history.pdf.

Mintzberg, H. (2004). Managers Not MBAs, Pearson Education, London.

Parsons, T. (1960). Structure and process in modem societies., Free Press, Glencoe, IL.

Pfeffer, J. (2007). 'A Modest Proposal: How We Might Change the Process and Product of Managerial Research', Academy of Management Journal, 50, pp. 1334-45.

Pfeffer, J. and C. T. Fong (2002). 'The End of Business Schools? Less Success than Meets the Eye.', Academy of Management Learning and Education, 1, pp. 7895.

Pfeffer, J. and G. R. Salancik (1978). The External Control of Organizations: A Resource Dependence Perspective., Harper and Row, New York.

Pfeffer, J. and R. I. Sutton (2006). 'Evidence-Based Management'. Harvard Business Review. pp. 63-74. Harvard Business School Publication Corp. 
Pfeffer, J. and R. I. Sutton (2007). 'Suppose We Took Evidence-Based Management Seriously: Implications for Reading and Writing Management', Academy of Management Learning \& Education, 6, pp. 153-55.

Podolny, J. M. (2009). 'The Buck Stops (and Starts) at Business School'. Harvard Business Review. pp. 62-67. Harvard Business School Publication Corp.

Porac, J. F., H. Thomas and C. Baden-Fuller (2011). 'Competitive Groups as Cognitive Communities: The Case of Scottish Knitwear Manufacturers Revisited.', Journal Of Management Studies. Classic, May, pp 646-664

Rousseau, D. M. (2006). '2005 presidential address - Is there such a thing as "evidence-based management"?', Academy of Management Review, 31, pp. 256-69.

Rousseau, D. M. and S. McCarthy (2007). 'Educating Managers From an EvidenceBased Perspective'. Academy of Management Learning \& Education. pp. 84101. Academy of Management.

Rynes, S. L. (2006). "'Getting on board" with AMJ: Balancing quality and innovation in the review process', Academy of Management Journal, 49, pp. 1097102.(?) 1102?

Schoemaker, P. J. H. (2008). 'The Future Challenges of Business: Rethinking Management Education', California Management Review, 50, pp. 119-39.

Segev, E., A. Raveh and M. Farjoun (1999). 'Conceptual maps of the leading MBA programs in the United States: core courses, concentration areas, and the ranking of the school', Strategic Management Journal, 20, pp. 549-65.

Sillince, J. A. A. and A. D. Brown (2009). 'Multiple organizational identities and legitimacy: The rhetoric of police websites', Human Relations, 62, pp. 182956.

Starkey, K. and S. Tempest (2009). 'From Crisis to Purpose', Journal of Management Development, 28, pp. 700-10.

Starkey, K. and N. Tiratsoo (2007). The business school and the bottom line, Cambridge University Press, Cambridge.

Suchman, M. C. (1995). 'Managing Legitimacy: Strategic and Institutional Approaches', The Academy of Management Review, 20, pp. 571-610.

The Economist (2007). 'Practically Irrelevant?'. Economist.com. 28th August ed. London.

Thomas, H. (2007). 'Business School Strategy and the Metrics for Success '. Journal of Management Development, 26, 1, pp 33-42 (reprinted in Global Focus, EFMD, 2009 pp 36-39)

Thomas, H. and X. Li (2009). 'Mapping globally branded business schools: a strategic positioning analysis', Management Decision, 47, pp. 1420-40.

Thomas, H. and A. Wilson (2009). 'An analysis of the environment and competitive dynamics of management research', Journal of Management Development, 28, pp. 668-84.

Tranfield, D. and K. Starkey (1998). 'The Nature, Social Organization and Promotion of Management Research: Towards Policy', British Journal of Management, $\mathbf{9}$, pp. 341-53.

University of Dallas at Texas (2011). 'World Wide Rankings - UTD Top 100 Business School Research Rankings'.

Van de Ven, A. and P. Johnson (2006). 'Knowledge for Theory and Practice', Academy of Management Review, 31, pp. 802-21.

Van de Ven, A. H. (2007). Engaged scholarship : a guide for organizational and social research, Oxford University Press, Oxford. 
Wedlin, L. (2011). 'Going global: Rankings as rhetorical devices to construct an international field of management education', Management Learning, 42, pp. 199-218.

Wensley, R. (2009). 'Research in UK Business Schools or Management Research in the UK?', Journal of Management Development, 28, pp. 718-27.

Whitley, R., A. B. Thomas and J. F. Marceau (1981). Masters of business : the making of a new elite?, London : Tavistock, 1981 (1984 [printing]).

Williams, A. P. O. (2010). The history of UK business and management education, Emerald, Bingley.

Willmott, H. (1995). 'Managing the Academics: Commodification and Control in the Development of University Education in the U.K', Human Relations, 48, pp. 993-1027.

Zammuto, R. (2008). 'Accreditation and the Globalization of Business', Academy of Management Learning \& Education, 7, pp. 256-68.

Zucker, L. G. (1987). 'Institutional Theories of Organization', Annual Review of Sociology, 13, pp. 443-64. 
Table 1: Evolution of business schools and associated legitimacy

\section{providers}

\begin{tabular}{|c|c|c|c|}
\hline $\begin{array}{l}\text { Generation \& } \\
\text { Time Period }\end{array}$ & $\begin{array}{l}\text { Behavioural } \\
\text { Characteristics }\end{array}$ & Implications & Legitimacy Providers \\
\hline $\begin{array}{l}1^{\text {st }} \text { Generation } \\
\left(\text { C. } 19^{\text {th }}-\text { Early }\right. \\
\left.\text { C. } 20^{\text {th }}\right)\end{array}$ & $\begin{array}{l}\text { Different } \\
\text { knowledge } \\
\text { structures, frames } \\
\text { of reference and } \\
\text { cognitive maps. } \\
\text { Different beliefs } \\
\text { about } \\
\text { management } \\
\text { education but } \\
\text { mainly vocational } \\
\text { trade-type models } \\
\text { focussing on } \\
\text { commercial and } \\
\text { administrative } \\
\text { practice }\end{array}$ & $\begin{array}{l}\text { Beliefs about } \\
\text { market boundaries } \\
\text { vary across } \\
\text { countries } \\
\text { Differential rates of } \\
\text { growth and } \\
\text { adoption across } \\
\text { countries } \\
\text { Influence of culture, } \\
\text { regulations, country } \\
\text { characteristics, and } \\
\text { languages evident } \\
\text { at local and } \\
\text { national level } \\
\text { Size of schools } \\
\text { tends to be } \\
\text { nationally } \\
\text { determined }\end{array}$ & $\begin{array}{l}\text { The creation of } \\
\text { managerial } \\
\text { employment by } \\
\text { industrialists, } \\
\text { entrepreneurial } \\
\text { individuals and the } \\
\text { state to cope with } \\
\text { larger } \\
\text { organisations } \\
\text { - Institutionalised } \\
\text { managerial } \\
\text { systems e.g. } \\
\text { accounting } \\
\text { practices }\end{array}$ \\
\hline $\begin{array}{l}2^{\text {nd }} \text { Generation } \\
\text { (Early C. } 20^{\text {th }}- \\
\text { 1970s) }\end{array}$ & $\begin{array}{l}\text { Strategic reference } \\
\text { points established } \\
\text { in countries - U.S. } \\
\text { model is key } \\
\text { reference point. } \\
\text { Imitative behaviour } \\
\text { at a local/ national } \\
\text { level. } \\
\text { The image and } \\
\text { identity of a } \\
\text { business school } \\
\text { becomes clear. } \\
\text { Institutionalising } \\
\text { processes. }\end{array}$ & $\begin{array}{l}\text { The identification of } \\
\text { national role } \\
\text { models and a } \\
\text { dominant industry } \\
\text { recipe means that } \\
\text { differences exist } \\
\text { among the key } \\
\text { drivers of: } \\
\text { - Governance } \\
\text { - Funding and } \\
\text { - endowment } \\
\text { - International } \\
\text { mindset } \\
\text { - Innovation } \\
\text { - Knowledge } \\
\text { transmission } \\
\text { - Corporate } \\
\text { linkages }\end{array}$ & $\begin{array}{ll}\text { - } & \text { National } \\
& \text { Governments } \\
\text { - Universities } \\
\text { - 'Feeder' } \\
\text { disciplines } \\
\text { (economics, } \\
\text { psychology) }\end{array}$ \\
\hline $\begin{array}{l}3^{\text {rd }} \text { Generation } \\
\text { (1970s - } \\
\text { present) }\end{array}$ & $\begin{array}{l}\text { Industry recipe is } \\
\text { established - } \\
\text { dominant }\end{array}$ & $\begin{array}{l}\text { Issues of image } \\
\text { and reputation } \\
\text { become important }\end{array}$ & $\begin{array}{ll}\text { - } & \text { Research rankings } \\
& \text { and citations } \\
\text { - } & \text { Globalised }\end{array}$ \\
\hline
\end{tabular}




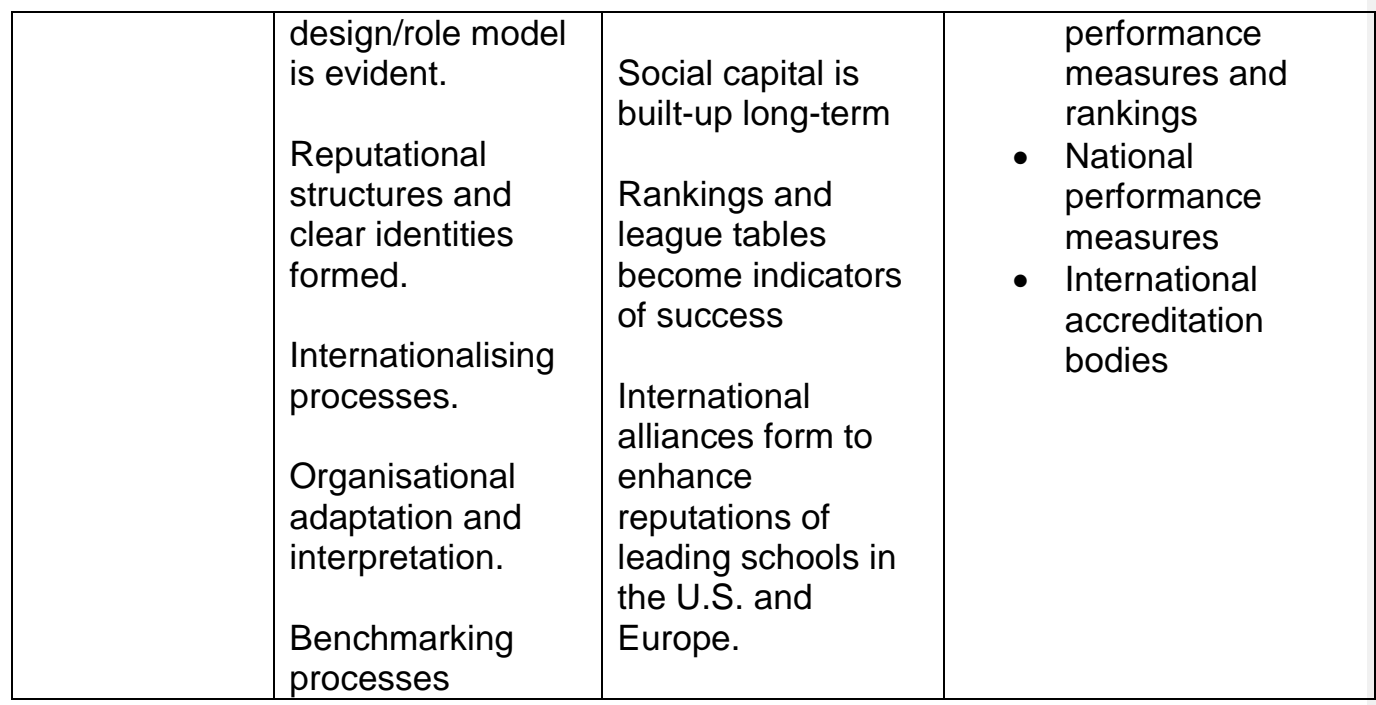

Source: Adapted from Antunes and Thomas, (2007) 
Table 2: Conflicting Sources of Legitimacy for Business Schools

\begin{tabular}{|l|l|l|}
\multicolumn{1}{l|}{} & Lack of Practical Relevance & Lack of Academic Rigour \\
\hline Research & $\begin{array}{l}\text { Business school research is too abstract } \\
\text { and irrelevant to the needs of practicing } \\
\text { managers. It does not attempt to solve } \\
\text { current managerial problems. }\end{array}$ & $\begin{array}{l}\text { Not enough business school research is } \\
\text { grounded in the methodological rigour of the } \\
\text { social sciences, it is often too case based } \\
\text { and discursive. }\end{array}$ \\
\hline Teaching & $\begin{array}{l}\text { Business school teaching is too } \\
\text { theoretical, and not sufficiently focused } \\
\text { on problems that managers actually } \\
\text { face. }\end{array}$ & $\begin{array}{l}\text { Business school teaching is too 'customer } \\
\text { focused' and not sufficiently distant from, } \\
\text { and critical of, management practice. }\end{array}$ \\
\hline MBAs & $\begin{array}{l}\text { MBAs, and business degrees generally, } \\
\text { do not produce well rounded managers } \\
\text { with leadership qualities. }\end{array}$ & $\begin{array}{l}\text { MBAs are, or for a long time were, seen as } \\
\text { a passport to career progression and } \\
\text { greater earning power. The business school } \\
\text { is seen as a 'finishing school'. }\end{array}$ \\
\hline $\begin{array}{l}\text { Impact for } \\
\text { practice }\end{array}$ & $\begin{array}{l}\text { Business education has made almost no } \\
\text { impression on practicing managers, and } \\
\text { has failed to impact business } \\
\text { performance. }\end{array}$ & $\begin{array}{l}\text { Business schools are partly culpable for } \\
\text { recent corporate scandals, and therefore } \\
\text { have had a negative impact on business } \\
\text { performance. }\end{array}$ \\
\hline Output & $\begin{array}{l}\text { many of those taking degrees in } \\
\text { benefit from their studies. Their degrees } \\
\text { do not prepare them for future careers. }\end{array}$ & $\begin{array}{l}\text { Firms simply cannot rely on the University } \\
\text { sector to supply the training/education that } \\
\text { their managers need. They do not } \\
\text { challenge students intellectually to develop } \\
\text { creative, imaginative thinking skills. }\end{array}$ \\
\hline
\end{tabular}

(Adapted from table 1 in Ivory et al., 2006, p. 7) 
Table 3: Strategies for Practice Engagement

\begin{tabular}{|l|l|}
\hline Strategies for Practice Engagement & Example Literatures \\
\hline Evidence-based research & (Pfeffer and Sutton, 2006, \\
& 2007; Rousseau, 2006; Rousseau and \\
& McCarthy, 2007) \\
\hline Pragmatism & (Starkey and Tempest, 2009) \\
\hline Translation & (Wensley, 2009) \\
\hline Engaged Scholarship & (Van de Ven and Johnson, 2006;Van de \\
& Ven, 2007) \\
\hline
\end{tabular}

Field Code Changed

Field Code Changed

Field Code Changed

Field Code Changed

Field Code Changed

Field Code Changed

Field Code Changed

Field Code Changed 
Table 4. University of Texas Top 100 Business Schools on Research

Contribution 2005-2009 by Country.

\begin{tabular}{|l|r|}
\hline Country: & Count of Business School in Top 100 \\
\hline USA & 72 \\
\hline Canada & 9 \\
\hline China & 5 \\
\hline Singapore & 4 \\
\hline The Netherlands & 3 \\
\hline France & 2 \\
\hline Australia & 2 \\
\hline Denmark & 1 \\
\hline United Kingdom & 1 \\
\hline Germany & 1 \\
\hline & $\mathbf{1 0 0}$ \\
\hline
\end{tabular}

(Adapted from: University of Dallas at Texas, 2011) 
Table 5: Selected regions from the top 120 schools worldwide ${ }^{1}$

\begin{tabular}{|c|c|c|c|}
\hline Schools & $\begin{array}{l}\text { Global Production Survey, } \\
\text { (Mangematin and Baden- } \\
\text { Fuller) World Rank (2005) } \\
\text { [Data 1992-2005] }\end{array}$ & $\begin{array}{l}\text { Financial Times } \\
\text { Research } \\
\text { Ranking (2006) }\end{array}$ & \begin{tabular}{|l} 
UT Dallas \\
Research \\
Ranking (2006) \\
\end{tabular} \\
\hline \multicolumn{4}{|l|}{$\underline{\text { UK }}$} \\
\hline London Business School* & 17 & 11 & 24 \\
\hline Manchester & 36 & 73 & - \\
\hline Nottingham & 42 & 73 & - \\
\hline Oxford & 57 & 51 & - \\
\hline Cambridge & 105 & 51 & - \\
\hline Warwick & 106 & 81 & - \\
\hline LSE & 110 & - & - \\
\hline Cranfield & 118 & 86 & - \\
\hline City & 120 & 86 & - \\
\hline \multicolumn{4}{|l|}{ Canada } \\
\hline$\overline{\text { Toronto }}$ & 29 & 23 & 37 \\
\hline Univ of British Columbia & 33 & 35 & 39 \\
\hline Univ of Western Ontario & 37 & 23 & 50 \\
\hline HEC Montreal & 63 & - & - \\
\hline Concordia & 67 & - & - \\
\hline Alberta & 77 & - & 78 \\
\hline Simon Fraser & 101 & - & 94 \\
\hline \multicolumn{4}{|l|}{ Europe } \\
\hline$\overline{\text { Erasmus }}$ & 18 & 81 & 80 \\
\hline Insead & 25 & 11 & 14 \\
\hline Tilburg & 27 & - & 55 \\
\hline Louvain & 61 & - & - \\
\hline Groningen & 65 & - & - \\
\hline Maastricht & 79 & - & - \\
\hline Ghent & 84 & - & - \\
\hline Copenhagen & 93 & - & - \\
\hline Eindhoven & 114 & - & - \\
\hline Bocconi & 117 & 73 & - \\
\hline Amsterdam & 124 & - & - \\
\hline \multicolumn{4}{|l|}{ Asia/Australia } \\
\hline HKUST (HK) & 44 & - & 29 \\
\hline NUS (SG) & 46 & 70 & 52 \\
\hline AGSM (Australia) & 49 & 51 & 70 \\
\hline Chinese Univ Hong Kong & 74 & - & - \\
\hline City Univ Hong Kong & 80 & - & 98 \\
\hline SMU (SG) & 85 & - & - \\
\hline Nanyang (SG) & 104 & 73 & 74 \\
\hline
\end{tabular}

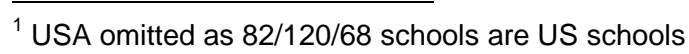


Source: Adapted from Mangematin and Baden-Fuller (2008) 